Portland State University

PDXScholar

\title{
Written narratives of language disordered and normal adolescents on two tasks
}

Antigone Howick Brown

Portland State University

Follow this and additional works at: https://pdxscholar.library.pdx.edu/open_access_etds

Part of the Rhetoric Commons, and the Speech and Hearing Science Commons Let us know how access to this document benefits you.

\section{Recommended Citation}

Brown, Antigone Howick, "Written narratives of language disordered and normal adolescents on two tasks" (1990). Dissertations and Theses. Paper 3973.

https://doi.org/10.15760/etd.5854

This Thesis is brought to you for free and open access. It has been accepted for inclusion in Dissertations and Theses by an authorized administrator of PDXScholar. Please contact us if we can make this document more accessible: pdxscholar@pdx.edu. 
AN ABSTRACT OF THE THESIS OF Antigone Howick Brown for the Master of Science in Speech Communication: Speech and Hearing Sciences presented August 2, 1990.

Title: Written Narratives of Language Disordered And Normal Adolescents on Two Tasks

APPROVED BY MEMBERS OF THE THESIS COMMITTEE:

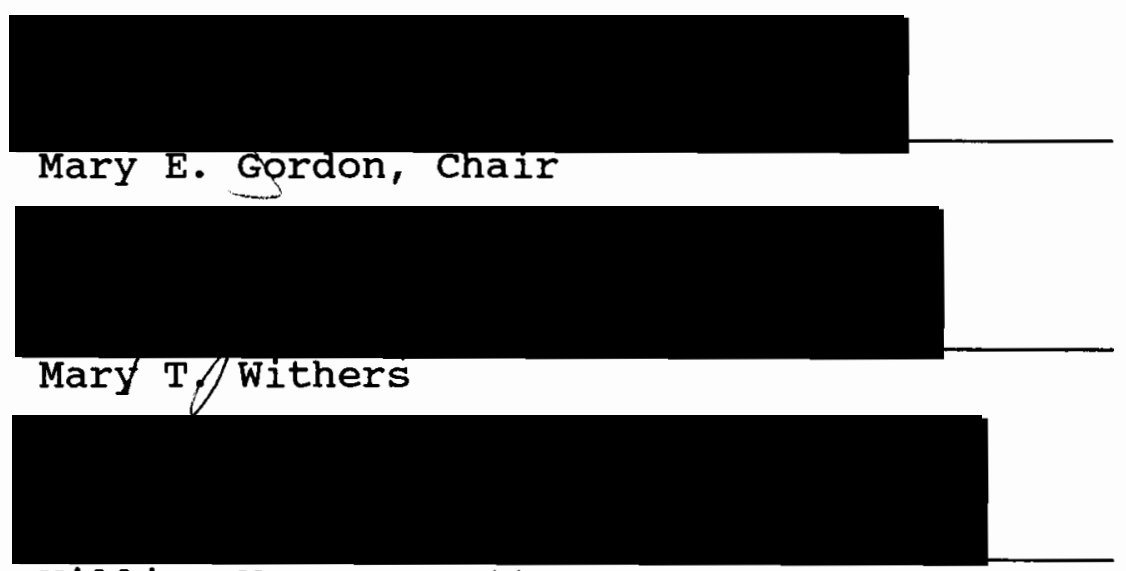

William M. McBurnett

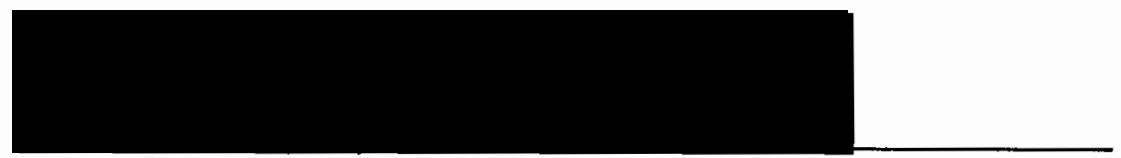

Carol L. Peterman

The majority of current research about narratives reflects the trend to apply story grammar analysis to children's oral narratives. As children progress through school, their academic performance is increasingly evaluated by their ability to express themselves with written language 
in a variety of forms, i.e., comparisons, expositions, critiques, hypothetical proposals, and abstract selfexpressions. Therefore, there is a need to apply research techniques to the written narratives of the older student in order to help in the identification of and intervention with language disordered adolescents in the area of written language. Because current research has typically applied story grammar analysis to oral narratives, this investigation is unique in its application of story grammar analysis to written narratives of adolescents.

The purpose of this study was to describe written narratives of language disordered adolescents by comparing their written narratives via story grammar analysis with those of normal adolescents. The written narratives were obtained by administering two tasks as required assignments within the English or communications classes of the two groups. Task A was to write about a personal experience and Task B was about an imaginary experience. This study used Merritt and Liles' adaptations (1987) of Stein and Glenn's procedures (1979) for story grammar analysis to describe the content of the narratives.

The following questions were addressed:

1) Do the written narratives of personal experiences and imaginary experiences produce different story schemes in language disordered and normal adolescents?

2) Are there differences between written narratives of 
personal experiences and written narratives of imaginary experiences for language disordered and for normal adolescents?

Twenty language disordered adolescents and twenty normal adolescents from the Beaverton School District who met the selection criteria served as subjects for this investigation, and ranged in age from 15 years, 2 months to 18 years, 6 months. The written narratives were transcribed into typescript by the investigator and then each utterance was identified as one or more of the six story grammar components. A two-way analysis of variance was performed to determine if differences existed between the two groups and the two tasks. The results indicated a statistically significant difference exists between the two groups on the story grammar components of setting, internal response and reaction. Between tasks, significant differences were found on the story grammar components of setting, initiating event, attempt category, direct consequence, and reaction.

In examining the resulting data from this study, it was concluded:

1. Language disordered adolescents did not use as many story grammar components as the normal group when writing about a personal or an imaginary experience.

2. Writing about an imaginary, goal-based event produces more appropriate usages of the story grammar components used than the stimuli given to obtain the 
personal experience stimuli in this investigation.

3. Whether part of an initial diagnostic assessment or as an ongoing evaluation over time, a story grammar analysis of written narratives is a useful approach to describe individuals' ability to apply story grammar rules that reveal their understanding and use of causally and temporally related information. 
WRITTEN NARRATIVES OF LANGUAGE DISORDERED AND NORMAL ADOLESCENTS ON TWO TASKS

by

ANTIGONE HOWICK BROWN

A thesis submitted in partial fulfillment of the requirements for the degree of

\author{
MASTER OF SCIENCE \\ in \\ SPEECH AND HEARING SCIENCES
}

Portland State University

1990 
TO THE OFFICE OF GRADUATE STUDIES:

The members of the committee approve the thesis of Antigone Howick Brown presented August 2, 1990.

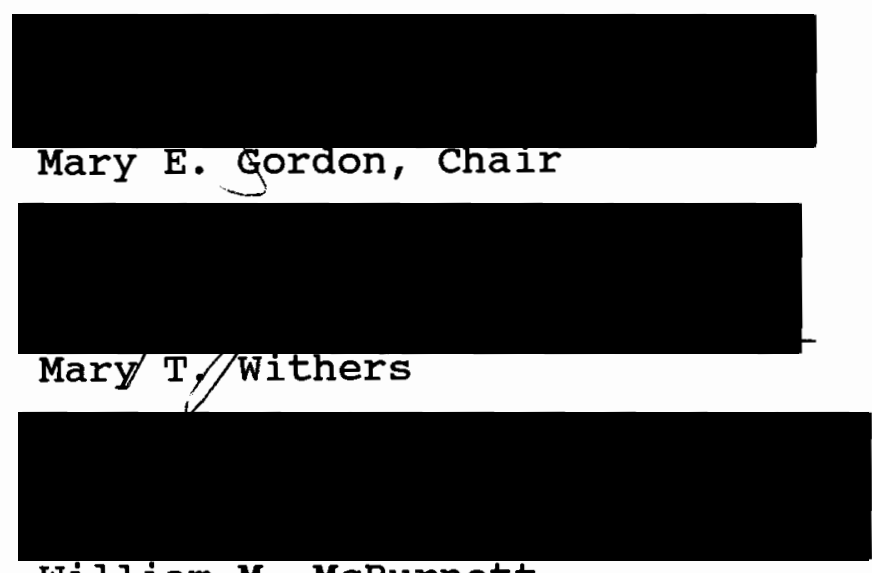

William M. McBurnett

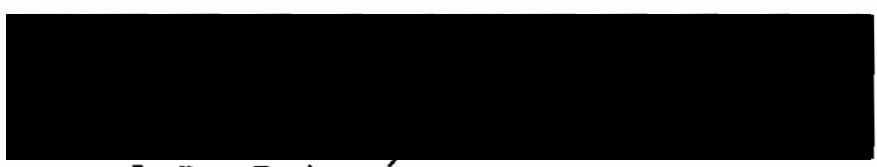

Carol L. Peterman

\section{APPROVED :}

Theodore G. Grove, Chair, Department of Speech Communication

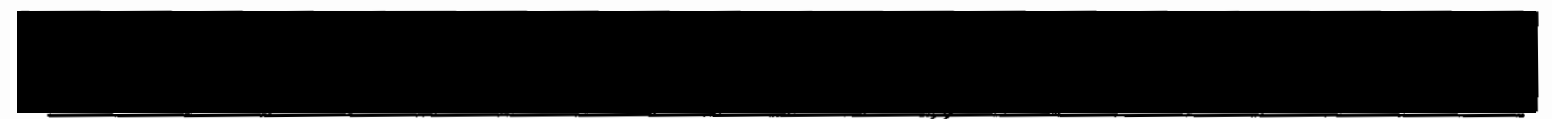

C. William Savery, Interim Vice Profrost for Graduate Studies and Research 


\section{ACKNOWLEDGEMENTS}

I wish to thank my advisor, Mary Gordon, for continuing to work with me while she was on vacation. Her participation in this project during the eleventh hour was instrumental in my completing this thesis.

I also wish to thank Max McBurnett of the Beaverton School District, and M.T. Withers of P.S.U for their participation and input.

Most of all, I wish to thank my husband and daughter for managing to get through this with me, for they were the ones who had to put up with the fall-out when things did not go as smoothly as anticipated. And to my brother Drew, who was always my role model for pursuing the road to higher education, thanks for the trip. 
TABLE OF CONTENTS

PAGE

ACKNOWLEDGEMENTS • • . . . . . . . . . . . . . . . $i i i$

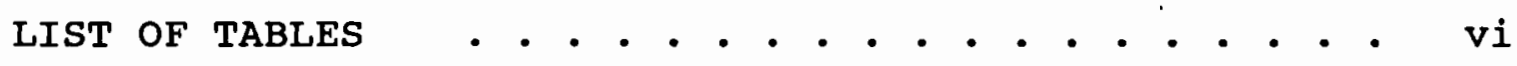

LIST OF FIGURES . . . . . . . . . . . . . . . . viii

CHAPTER

I INTRODUCTION AND STATEMENT OF PURPOSE . . . . 1

Introduction . . . . . . . . . . . 1

Statement of Purpose . . . . . . . . . 2

II REVIEW OF THE LITERATURE . . . . . . . . . 4

Written Narratives of Adolescents . . . . 4

Development of Writing 5

Assessment of Written Language 9

Summary . . . . . . . . . . . . . . 11

II METHODS . . . . . . . . . . . . . . 13

Subjects . . . . . . . . . . . 13

Experimental Subjects 13

Control Subjects 14

Instrumentation . . . . . . . . . 15

Procedures . . . . . . . . . . 15

Reliability . . . . . . . . . 17

Scoring Data and Analysis . . . . . . 18 
IV RESULTS AND DISCUSSION . . . . . . . . . . 19

Results . . . . . . . . . . . 19

Discussion . . . . . . . . . 29

Limitations . . . . . . . . . . . 34

V SUMMARY AND IMPLICATIONS . . . . . . . . 35

Summary . . . . . . . . . . . 35

Implications . . . . . . . . . . . 37

Clinical 37

Research 39

REFERENCES

•. . . . . . . . . . . . . . . . .

APPENDICES

A STORY COMPONENT CRITERIA . . . . . . . . . 43

B LETTER TO PARENTS FOR INFORMED CONSENT . • . 45

C STORY GENERATION SCORING PROCEDURE . . . . . 47

D TASK A PROTOCOL . . . . . . . . . . 49

E TASK B PROTOCOL ............. 51

F STORIES USED FOR RATER TRAINING . . . . . 53

G RAW SCORES OF LANGUAGE DISORDERD AND

NORMAL ADOLESCENTS ON TASKS A AND B . . 56

H REPRESENTATIVE SAMPLES OF WRITTEN

NARRATIVES . . . . . . . . . . . 59 


\section{LIST OF TABLES}

TABLE

PAGE

I Hierarchy of Written Language Development . . 5

II Developmental stages of Writing for

Nonhandicapped Students . . . . . 8

III Means and Standard Deviations for Tasks $A$ and

B Combined for the Language Disordered and Normal Groups . . . . . . . . 21

IV Two-Way Analysis of Variance of Language

Disordered and Normal Adolescents'

Written Narratives on Task A and Task B 22

V t-Test Results on story Grammar Components

Found to be significant by the Two-Way

ANOVA for the Language Disordered and

Normal Adolescent Groups for Task A . . 24

VI $\quad t$-Test Results on story Grammar Components

Found to be significant by the Two-Way

ANOVA for the Language Disordered and

Normal Adolescents Groups for Task B . . 25

VII Means and standard Deviations Combined for

the Language Disordered and Normal Group

for Task A and Task B. . . . . . 26 
VIII $\underline{t}$-Test Results on Story Grammar Components Found to be Significant by the Two-Way ANOVA Between Task A and Task B for the Language Disordered Group . . . . . 27

IX $t$-Test Results on Story Grammar Components Found to be significant by the Two-Way ANOVA Between Task $A$ and Task $B$ for the Normal Adolescent Group . . . . . . 28 


\section{LIST OF FIGURES}

FIGURE

PAGE

1. Means and Standard Deviations of Language

Disordered and Normal Adolescents Use

of story Grammar components in Written

Narratives for Task A and Task B. . . 20 


\section{CHAPTER I}

\section{INTRODUCTION AND STATEMENT OF PURPOSE}

\section{INTRODUCTION}

The assessment of written language is a critical component of language evaluation for language disordered adolescents. As students progress through school, the average adolescent is expected to be capable of writing on topics in a variety of forms. The focus of measuring the achievements of students increasingly relies on their written language abilities. Therefore, obtaining and analyzing written language samples has become part of the screening and diagnostic evaluation procedures for many speech-language pathologists who work with adolescents.

Lahey (1988) defined narratives as "a report of what happened; they can be real or imaginary" (p. 267). Research in the area of written narratives of adolescents has received little attention. Rather the focus of narrative research, albeit recent, has been on oral narratives (Johnston, 1982; Merritt \& Liles, 1987; Roth \& Spekman, 1986; Westby, 1984). Traditionally, standardized tests used to assess language have examined oral and written forms of language, but only at the word and sentence levels, which 
merely represent parts or fragments of language. Narratives, however, rely on unity and cohesion to be meaningful as a whole unit, thereby being representative of an individual's use and understanding of language by revealing how that individual organizes language.

Frequently, diagnostic evaluations at the secondary level utilize formal standardized tests, along with oral and written language samples. Language samples are considered to be an integral part of a language evaluation, yet the analysis of written samples of adolescents is a largely neglected area of research in the field of speech-language pathology.

Comparing written narratives of normal adolescents with those written by language disordered adolescents would provide speech-language pathologists with norm-referenced data to aid in the identification of language disordered adolescents.

\section{STATEMENT OF PURPOSE}

The purpose of this study was to describe written narratives of adolescents who are language disordered by comparing their written narratives with those of normal adolescents using a story grammar analysis. Additionally, written narratives about a personal experience were compared with written narratives about an imaginary event, i.e., one that the student had not personally experienced. The 
following research questions were addressed:

1. Do the written narratives of personal experiences and imaginary experiences produce different story schemes in language disordered and normal adolescents?

2. Are there differences between written narratives of personal experiences and written narratives of imaginary experiences for language disordered and for normal adolescents?

For the purposes of this study, the term adolescent shall refer to a student between the ages of 15 years to 18 years, 6 months, who attends a secondary school (grades 1012). The term language disorder shall refer to

$$
\begin{aligned}
& \text { any disruption in the learning or use of one's } \\
& \text { native language as evidenced by language behaviors } \\
& \text { that are different from (but not superior to) those } \\
& \text { expected given a child's chronological age (Lahey, } \\
& \text { 1988, p. 21). }
\end{aligned}
$$

The six story grammar components (setting, initiating event, internal response, attempt, direct consequence, and reaction) used in the analysis process of this investigation are defined in detail in Appendix $A$. 


\section{CHAPTER II}

\section{REVIEW OF THE LITERATURE}

\section{WRITTEN NARRATIVES OF ADOLESCENTS}

In order to document and describe language behaviors of adolescents adequately, it is necessary for speech-language pathologists to use a method of analysis that provides information other than numerical scores. Numerical scores are obtained from standardized tests that characteristically assess language at the word or sentence level (Merritt \& Liles, 1989). In so doing, clinically significant information about changes in language disordered adolescents' communication deficiencies are undocumented as the students mature. Ideally, It would be most productive for the speech-language pathologist to have written narratives described from a perspective that provides information on the overall coherence and competence of the written piece, taking into account for whom the writer is writing, and for what purpose. Understanding the development of writing, expectations of adolescents' written work, and traditional assessment procedures will provide a foundation from which to view written narrative assessment. 
Development of Writing

It is necessary to have an understanding of written language development before reviewing the kinds of assessments that measure written language competence. The literature reflects two theories of writing development. Litowitz (1981) exemplified one theory by contending that writing is an activity that is acquired only after the acquisition of the prerequisite skills of listening, speaking, and reading. Johnson and Myklebust (1967) and Myklebust $(1965,1973)$ also held this viewpoint by illustrating the hierarchy of written language development as shown in Table $I$.

TABLE I

HIERARCHY OF WRITTEN LANGUAGE DEVELOPMENT

Written Expression

Reading (Receptive)

oral Expression

oral Receptive

This hierarchy illustrates that the first level, oral receptive, must be intact before development proceeds to oral expression. This hierarchial pattern continues up through reading to written expression. If there are problems with language acquisition at any one level, the next higher level will be affected.

Litowitz (1981) described the development of written 
language as a complex process because it requires the writer to relate to the world in an indirect, abstract way. Additionally, the process of writing itself requires the writer to become skilled at learning the orthographic symbol system.

In contrast to Litowitz (1981), Poplin (1983) discussed research on the normal development of written language that challenges the concept that development of oral language and reading precede the ability to write. Dagenais and Beadle (1984) stated, "Most children attempt to write before they attempt to read". Research by Chomsky (1971), Gundlach (1982), and Read (1981) supported this observation by noting that, prior to attending school, children with access to writing materials, exposure to the alphabet, and a variety of writing in stories will spontaneously generate written messages. Poplin (1983) ascertained that the development of writing is an example of form following function, based on children's communicative intents. Poplin's (1983) examples included children's apparent scribbling that they translate into purposeful messages such as, "I love you", "Keep out", and "Don't touch". She also cited children's labeling of their own art work to be an early function of written expression, followed by an interest in form. For example, children frequently ask adults to write a word, very often their own first name, which has obvious meaning. Those children will then copy the example, approximating it as 
precisely as they can, thereby addressing form.

Dagenais and Beadle (1984) have described a sequence of written language development for nonhandicappd students by adapting the developmental stages of writing (see Table II) from Burrows (1971) and Moffett (1968).

Cambourne (1988) emphasized the notion of not separating reading and writing, defined reading as comprehension, and described written language as the integration of construction and comprehension, whereby the "writers construct texts for potential readers to comprehend" (p. 183). Cambourne (1988) further illustrated this point by stating:

Readers can read without necessarily being writers or knowing a great deal about writing and how it's done. But writers must be readers, and this creates a kind of language and thinking behaviour which is quite unique (p. 184).

When writers read and re-read their own work, they are consciously raising their awareness of how to organize thoughts and meaning (Cambourne, 1988). Further delineation of the writing process by Cambourne included the subconscious components of intention (the reason for writing something), decision making (purpose, audience, information, content, and procedure), and selection (linguistic options available and their organization), and the observable (overt behavior) components of reading, writing down, and talking. The intent of this writing process is to create meaning, and throughout students' education, they will be 
TABLE II

DEVELOPMENTAL STAGES OF WRITING FOR NONHANDICAPPED STUDENTS

Preschool, Kindergarten, Grade 1

Grade 2

Grade 3

Grades $4 \& 5$

Grade 6
Telegraphic statements may stand for complex ideas and whole accounts of inner speech or imaginations. Verbtense switching is common. Repetitious vocabulary and sentence forms.

Many characters and actions are introduced. These may be scarcely related and may have no common thread. Animal characters are frequent and tend to be used as representatives of human figures in the child's life. Focus is on action, on having something happen. As a result, the focus is often on the ending, rather than the details leading up to the ending.

Child moves away from egocentric world by changing from monologues to dialogues and narratives. Content involves more complex time and event relationships. Child includes word pictures, impressions, figurative and literal comparisons, rich vocabulary.

Complex ideas and sentence structures are used. Child is able to write for a purpose, select a point of view, revise for content and form, elaborate, and proofread. Content shows a deeper sensitivity to experience.

Complexity and sophistication of vocabulary and content continues. Content may begin to show a degree of social criticism or irony as the child starts to "test" superficial social values. 
called upon to utilize the writing process.

It is assumed that junior high students need less direction and interaction when writing because their writing skills should be at a complex level (Dagenais \& Beadle, 1984). Alley and Deshler (1979) and Schumaker and Deshler (1984) reported that the average adolescent is capable of writing comparisons, expositions, critiques, hypothetical proposals, and abstract self-expressions. However, Martlew (1986) stated, "It is important to recognize that developments are still proceeding through adolescence and that immaturity in written language ability can be found at almost any age" (p. 119).

Understanding how written language develops should allow one to assess normal written language development and identify written language disorders. Since the research clearly indicates two schools of thought regarding the development of written language, it naturally follows that assessments will differ in what they purport to assess and how that information is interpreted. This makes the analysis of writing more difficult especially when trying to identify a disorder in the area of written language.

\section{Assessment of Written Language}

Assessment of written language can be divided into formal or standardized tests, and clinician-designed tests. The function of standardized tests is to separate language 
impaired individuals from those who are not (Leonard, Prutting, Perozzi, \& Berkley, 1978). Formal tests compare a child's current level of linguistic functioning with others of the same age and cultural group (Bloom \& Lahey, 1978). The resulting score from a standardized test does not generally provide a valuable description of what language features to consider when developing intervention strategies (Leonard et al., 1978). Additionally, many of the available standardized tests measure components of written language (e.g., punctuation, spelling) that are given less focus by speech-language pathologists and have neglected to look at form, content, and use in a narrative format, which are important aspects when working with language disordered students.

Clinician-designed or nonstandardized measures can provide speech-language pathologists with valuable descriptions of language behavior. Leonard et al. (1978) stated, "The use of nonstandardized measures is essential in gaining sufficient information about the child's linguistic system in order to devise effective intervention strategies" (p. 371).

Johnston (1982) summarized approaches to oral narrative analysis. She described the story grammar analysis approach of Stein and Glenn (1979) as the underlying organizational rules of narration, and stated that an individual competent in story telling will formulate 
the narrative so that the listener can understand. Westby, Dongen, and Maggart (1989) stated that the use of narrative discourse in everyday lives is evidence of "narrative thought as a way to organize the world and make sense out of it" (p. 63). Merritt and Liles (1989) stated that the formal set of story grammar rules "identify stable patterns of causally and temporally related information most often found in stories" (p. 438). They adapted Stein and Glenn's (1979) story grammar analysis to research oral narratives during story retelling and story generation. The stories used for retelling were adaptations of the two written stories, "Buried Alive" and "Shipwrecked". These were selected by Merritt and Liles (1987) because "each story text in its original form was consistent with the internal structure of story grammar" (p. 439). Since Merritt and Liles applied the story grammar analysis to an existing written format, it follows that this same story grammer analysis could be applied to written narratives generated by adolescents.

\section{SUMMARY}

Current research suggests that writing develops simultaneously with speaking and reading rather than in a sequential fashion, and that it develops out of a need, or function, that is meaningful to the child. A meaningful analysis for the speech-language pathologist is one that 
provides a description of language disordered adolescents' language behaviors or patterns that, when compared to descriptions of language behaviors of normal adolescents of similar demographics, provides clinically significant results indicating where the student is developmentally and strategies to facilitate further development. 


\title{
CHAPTER III
}

\author{
METHODS
}

SUBJECTS

\section{Experimental Subjects}

The language-disordered students in this investigation were selected from the caseloads of three speech-language pathologists in all three secondary schools in the Beaverton School District in oregon. Twenty subjects were selected from the twenty-one students who met the following criteria:

1. history of a language disorder diagnosed in elementary school;

2. ongoing diagnosis of language impairment requiring language management services;

3. normal vision and hearing;

4. fine motor control as judged by the investigator to be adequate to complete the written language tasks;

5. between $15: 0$ and $18: 6$ years of age;

6. attending a grade commensurate, within one year, of the student's chronological age;

7. previous diagnostic testing results, language sample, and teacher observations that indicate a mild to moderate language impairment; 
8. no history or evidence of an organic problem and not on medication for a neurological disorder;

9. English as the primary language;

10. no known drug or related emotional problem; and

11. parent or guardian signed release form giving permission for participation in this study (Appendix B).

The 12 boys and 8 girls comprising the languagedisordered group were between the ages of 16:0 and 18:6 with a mean age of $17: 1$.

\section{Control Subjects}

Twenty students who attended schools in the same district as the language disordered subjects comprised the control group. The 8 males and 12 females comprising the control group were between the ages of $15: 8$ and $18: 4$ with a mean age of 16:3. Randomly selected students included in the control group also met the following criteria:

1. normal hearing and vision;

2. attending a grade commensurate with the student's chronological age;

3. no school record of having been referred for, or received, any type of educational or language support services;

4. parent or guardian signed release form giving permission for participation in this study (Appendix B);

5. English as the primary language; and

6. no known drug or related emotional problem. 
INSTRUMENTATION

Written narratives of a personal experience (PE) and an imaginary experience (IE) were scored in a like manner. Each written utterance was identified as one of six possible story grammar components: setting, initiating event, internal response, attempt, direct consequence, and reaction. This study used Merritt and Liles' (1987) adaptations of Stein and Glenn's procedures (1979). See Appendix A for detailed definitions. Scoring procedures adapted by Merritt and Liles (1987) for oral story generation were modified for use in this investigation of written narrative analysis (Appendix $C$ ).

\section{PROCEDURES}

Written narratives were obtained from the language disordered subjects in their communication classes taught by speech-language pathologists. Written narratives from the control subjects were obtained in their English classes taught by their regular classroom teachers. Task $A$ (PE) and Task B (IE) were administered as an assignment on different days to assure that students had a complete class period ( 55 minutes), if necessary, to complete each task. Half of the classes were randomly selected to have Task $A$ administered first, while the other half began with Task B. Task A was to compose a written narrative based on a personal 
experience (PE). The subjects were given lined paper with printed directions at the top of the first page (Appendix D). The administrator, who was either the regular classroom teacher in the English class or one of three speech-language pathologists in the communication class, then gave the same instructions verbally: "Describe the way your day usually goes, from beginning to end". If a student made any inquiries, the direction was rephrased as, "Describe the way your day is most of the time, from beginning to end".

Task B was to compose a written narrative of an imaginary experience (IE). This was obtained by providing the subjects with a printed story stem (Appendix E) originally written by Merritt and Liles (1989). Merritt and Liles wrote this story stem so it would "include a human protagonist and setting information and was designed to evoke images of an adventure involving a series of goalbased events" (p. 439). The administrator instructed the subjects to read the story stem silently while the administrator read it aloud. They were then instructed to "Think about what might happen next and write a good story". At the completion of each task, the administrator read each narrative and asked for clarification from the individual students for writing that was illegible.

If the student met the criteria for a control subject or a language disordered subject, his/her parent/guardian was first contacted via phone by the investigator and given 
a brief description of this study. A release form (Appendix B) was then sent to the parent or guardian to obtain written permission to include the student's written narratives in this investigation. Reliability

A training session was conducted prior to the actual reliability testing by the investigator. The raters were given printed definitions of the six story grammars to be identified (Appendix A), and two transcribed stories, titled "Buried Alive" and "Shipwrecked" (Appendix F). These two stories were used in two studies conducted by Merritt and Liles $(1987,1989)$ because "each story text in its original form was consistent with the internal structure of story grammar" (p. 439). The raters read each text, then labeled each utterance as one of the six possible story grammar components. The two raters and investigator discussed their scoring after each practice written narrative to acheive $100 \%$ agreement.

In order to assess investigator reliability for identifying story grammar structures, six written narratives, three from Task $A$ (PE) and three from Task $B$ (IE), were randomly selected from the language-disordered group and the same number of narratives from the control group. These narratives were then given to two speechlanguage pathologists holding a Masters Degree in SpeechLanguage Pathology. These reliability raters were 
responsible for identifying each written utterance in the selected written narratives as one of the six story grammar components, as previously described (Appendix A).

Percentage of agreement for interjudge reliability was $94 \%$ between the investigator and the two raters. Intrajudge reliability for the investigator was $98.7 \%$.

\section{SCORING AND DATA ANALYSIS}

Each original written narrative was transcribed verbatim into typescript allowing the written statements to be numbered to complete a story grammar component analysis. Raw scores for each story grammar component were obtained for each written narrative from each task. The raw data reflecting the frequency of use of each component was computed for each group of subjects for both tasks. An analysis of individual story grammar components across tasks (i.e., PE and IE), across groups (i.e., language disordered and normal adolescents), and for group/task interaction was completed using a two-way analysis of variance (ANOVA). Additionally, post hoc $\underline{t}$-test analysis were done on significant findings from the two-way ANOVA. 
CHAPTER IV

\section{RESULTS AND DISCUSSION}

\section{RESULTS}

This study was conducted to test for significant differences across tasks and between groups in order to describe, via story grammar analysis, written narratives of adolescents who are language disordered and written narratives of normal adolescents. In addition to comparing these two groups of adolescents, the performance of each group on two different tasks were compared using story grammar analysis. Task A was writing about a personal experience while Task B involved writing about an imaginary experience. Raw data appear in Appendix G.

The first research question asked was: Do the written narratives of personal experiences and imaginary experiences produce different story schemes in language disordered and normal adolescents? A summary of the means and standard deviations for each group on each task is reported for each of the six story grammar components in Figure 1 and Table III shows the means and standard deviations for both tasks combined for each group.

The data were analyzed using a two-way analysis of 
SETTING

TASK A TASK B

\begin{tabular}{l|r|r|}
\hline IANG. & $\bar{x}=6.80$ & $\bar{x}=5.50$ \\
DIS. & $S D=6.35$ & $S D=3.65$ \\
\hline NORMAL & $\bar{x}=19.75$ & $\bar{x}=13.70$ \\
$S D=8.90$ & $S D=7.89$ \\
\hline
\end{tabular}

INITIATING EVENT

TASK A TASK B

\begin{tabular}{l|l|l|}
\hline LANG. & $\overline{\mathrm{x}}=16.85$ & $\overline{\mathrm{x}}=13.15$ \\
DIS. & $\mathrm{SD}=8.95$ & $\mathrm{SD}=8.36$ \\
\hline & $\overline{\mathrm{x}}=23.10$ & $\overline{\mathrm{x}}=12.50$ \\
\hline & $\mathrm{SD}=10.59$ & $\mathrm{SD}=6.19$ \\
\hline
\end{tabular}

INTERNAL RESPONSE

TASK A TASK B

\begin{tabular}{l|c|c|}
\hline LANG. & $\overline{\mathrm{x}}=2.30$ & $\overline{\mathrm{x}}=4.45$ \\
DIS. & $\mathrm{SD}=4.45$ & $\mathrm{SD}=4.11$ \\
\hline$\overline{\mathrm{x}}=7.20$ & $\overline{\mathrm{x}}=7.45$ \\
$\mathrm{SD}=7.24$ & $\mathrm{SD}=5.31$ \\
\hline
\end{tabular}

ATTEXPT

TASK A TASK B

\begin{tabular}{|c|c|c|}
\hline $\begin{array}{l}\text { LANG. } \\
\text { DIS. }\end{array}$ & $\begin{array}{r}\bar{x}=.05 \\
S D=.22\end{array}$ & $\begin{aligned} \bar{x} & =3.25 \\
S D & =3.74\end{aligned}$ \\
\hline NORMAL & $\begin{array}{r}\bar{x}=.55 \\
S D=1.82\end{array}$ & $\begin{aligned} \bar{x} & =3.80 \\
S D & =3.41\end{aligned}$ \\
\hline
\end{tabular}

DIRECT CONSEOUENCE

TASK A TASK B

\begin{tabular}{|c|c|c|}
\hline $\begin{array}{c}\text { LANG. } \\
\text { DIS. }\end{array}$ & $\begin{aligned} \bar{x} & =.15 \\
S D & =.67\end{aligned}$ & $\begin{aligned} \bar{x} & =3.35 \\
S D & =3.65\end{aligned}$ \\
\hline NORMAL & $\begin{array}{r}\bar{x}=.50 \\
S D=1.24\end{array}$ & $\begin{array}{r}\bar{x}=3.60 \\
S D=2.72\end{array}$ \\
\hline
\end{tabular}

\section{REACTION}

TASK A

TASK B

\begin{tabular}{l|r|r|}
\multicolumn{1}{l|}{$\begin{array}{r}\overline{\mathrm{x}}=.15 \\
\text { DIS. }\end{array}$} & $\mathrm{SD}=.67$ & $\mathrm{SD}=.22$ \\
\hline NORMAL & $\overline{\mathrm{x}}=.05$ & $\overline{\mathrm{x}}=1.25$ \\
$\mathrm{SD}=.22$ & $\mathrm{SD}=1.59$ \\
\hline
\end{tabular}

Figure 1. Means $(\bar{x})$ and standard deviations (SD) of language disordered and normal adolescents use of story grammar components in written narratives for personal (Task $A$ ) and imaginary experiences (Task B). 
TABLE III

MEANS AND STANDARD DEVIATIONS FOR TASKS A (PERSONAL EXPERIENCE) AND B (IMAGINARY EXPERIENCE) COMBINED FOR THE LANGUAGE DISORDERED AND NORMAL GROUPS

Measure

Group

Mean

SD

Language Disordered

6.15

5.15

Setting

Normal

16.73

8.85

Initiating

Event

Language Disordered

15.00

8.75

Normal

17.80

10.11

Language Disordered

3.38

4.37

Internal

Normal

7.33

6.27

Attempt

Language Disordered

1.65

3.05

Normal

2.18

3.16

Language Disordered

1.75

3.05

Direct

Consequence

Normal

2.05

2.61

Reaction

Language Disordered

.10

.50

Normal

.65

1.27

variance (ANOVA) to determine whether significant

differences between groups existed. By group, the story

grammar components of setting, internal response, and reaction were found to be statistically significantly 
TWO-WAY ANALYSIS OF VARIANCE OF LANGUAGE DISORDERED AND NORMAL ADOLFSCENTS' WRITTEN NARRATIVES ON TASK A (PERSONAL EXPERIENCE) AND TASK B (IMAGINARY EXPERIENCF)

\begin{tabular}{|c|c|c|c|c|c|}
\hline $\begin{array}{l}\text { STORY GRAMNER } \\
\text { COMPONENT }\end{array}$ & SOURCE & $\begin{array}{l}\text { SUM OF } \\
\text { SQUARES }\end{array}$ & DF MEAN-SQUARE & F-RATIO & PROBABILITY \\
\hline
\end{tabular}

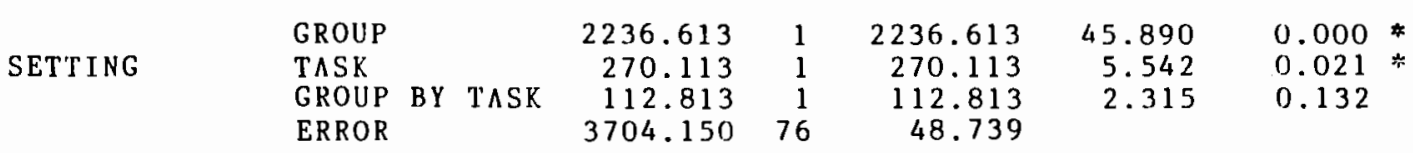

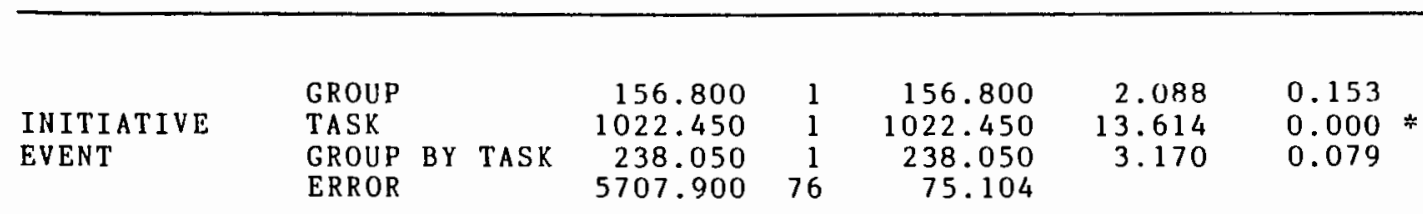

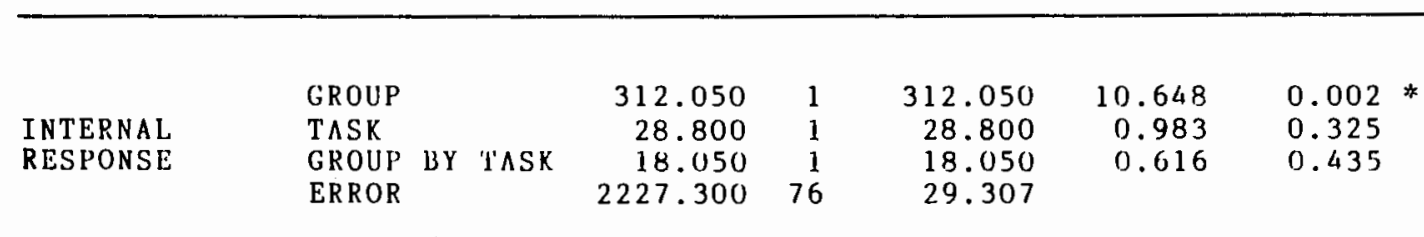

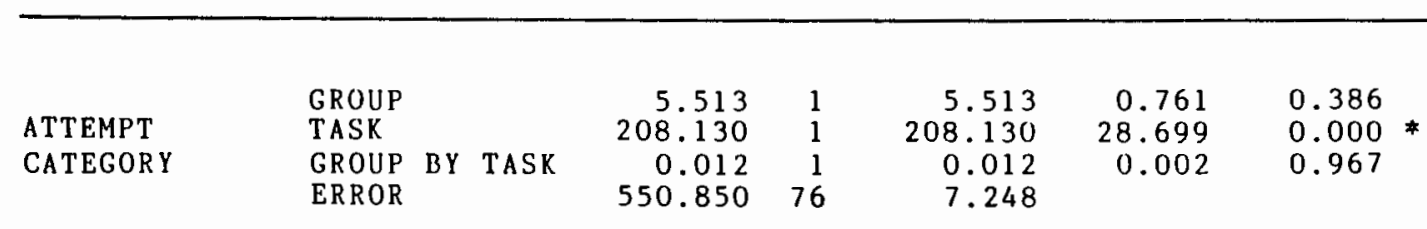

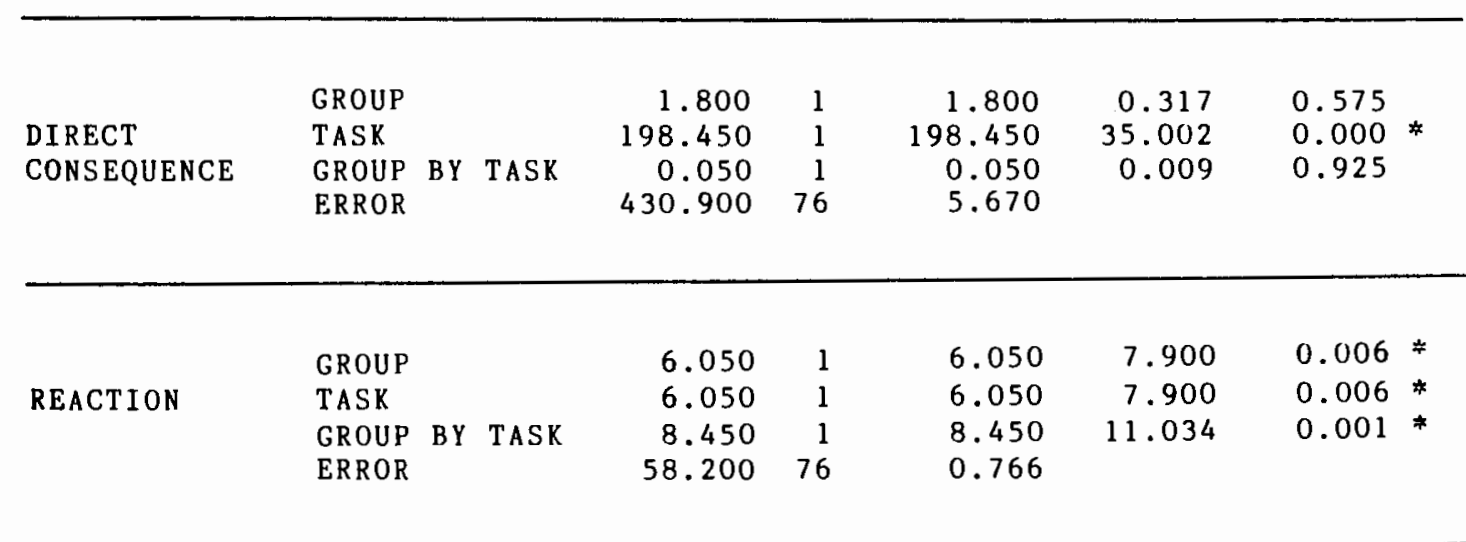


different at or beyond the .05 level of probability (Table IV). The story grammar component of setting yielded means of 6.8 and 5.5 for tasks $A$ and $B$, respectively, for the language disordered group. The normal group had means of 19.75 and 13.70 for tasks $A$ and $B$, respectively, for the setting component. Both groups used more setting statements for Task A than for Task B, though the overall amount used by the normal group was greater than that used by the language disordered group. Means for the internal response category were 2.30 and 4.45 for tasks A and B, respectively, for the language disordered group, while the normal group means were 7.20 and 7.45 , for tasks $A$ and $B$. These data indicate that both groups included more internal response components for Task B than they did for Task A. Means for the reaction category were .15 and .05 for tasks $A$ and $B$, respectively, for the language disordered group, and the mean number of reaction statements for the normal group was .05 and 1.25 on tasks $A$ and $B$, respectively. The other three story grammar components, i.e., initiating event, attempt, and direct consequence were not found to be statistically significantly different.

Post hoc $\underline{t}$-tests for independent means were completed for both tasks on those story grammar components found to be significant by group based on the ANOVA results. The story grammar components of setting and internal response were found to be significant for the personal experience task 
(Task A) when the two groups were compared, while the component of reaction was not (Table V). t-test results did not indicate a significant difference for internal response on the imaginary experience task (Task B) (Table VI). However, the components of setting and reaction were shown to be significant for Task B when comparing the two TABLE V

t-TEST RESULTS ON STORY GRAMMAR COMPONENTS FOUND TO BE SIGNIFICANT BY THE TWO-WAY ANOVA FOR THE LANGUAGE

DISORDERED AND NORMAL ADOLESCENT GROUPS FOR TASK A (PERSONAL EXPERIENCE)

\begin{tabular}{ll} 
Measure & Group \\
\hline Language
\end{tabular}

$\begin{array}{lll}\text { Setting Disordered } & 6.80 & 6.35\end{array}$

Normal $\quad 19.75 \quad 8.90$

$38-5.500 \quad .000 *$

Normal

\begin{tabular}{|c|c|c|c|c|c|c|}
\hline $\begin{array}{l}\text { Internal } \\
\text { Response }\end{array}$ & $\begin{array}{l}\text { Language } \\
\text { Disordered }\end{array}$ & 2.30 & & 88 & -2579 & $014 *$ \\
\hline & Normal & 7.20 & 7.23 & & & \\
\hline
\end{tabular}

\begin{tabular}{|c|c|c|c|c|c|c|}
\hline Reaction & $\begin{array}{l}\text { Language } \\
\text { Disordered }\end{array}$ & .15 & .67 & & & \\
\hline & Normal & .05 & .22 & 38 & .632 & .531 \\
\hline
\end{tabular}

* = Significant $(p \leq .05)$

groups (Table VI). In all cases, the normal group performed better than the language disordered group. The second question asked was: Are there differences 
TABLE VI

t-TEST RESULTS ON STORY GRAMMAR COMPONENTS FOUND TO BE SIGNIFICANT BY THE TWO-WAY ANOVA FOR THE LANGUAGE DISORDERED AND NORMAL ADOLESCENT GROUPS FOR TASK B (IMAGINARY EXPERIENCE)

\begin{tabular}{|c|c|c|c|c|c|c|}
\hline Measure & Group & Mean & S.D. & $d f$ & t-value & $\mathbf{p}$ \\
\hline setting & $\begin{array}{l}\text { Language } \\
\text { Disordered } \\
\text { Normal }\end{array}$ & $\begin{array}{r}5.50 \\
13.70\end{array}$ & $\begin{array}{l}3.65 \\
7.89\end{array}$ & 38 & -4.219 & $.000 *$ \\
\hline $\begin{array}{l}\text { Internal } \\
\text { Response }\end{array}$ & $\begin{array}{l}\text { Language } \\
\text { Disordered } \\
\text { Normal }\end{array}$ & $\begin{array}{l}4.45 \\
7.45\end{array}$ & $\begin{array}{l}4.11 \\
5.31\end{array}$ & 38 & -1.999 & .053 \\
\hline Reaction & $\begin{array}{l}\text { Language } \\
\text { Disordered } \\
\text { Normal }\end{array}$ & $\begin{array}{r}.05 \\
1.25\end{array}$ & $\begin{array}{r}.22 \\
1.59\end{array}$ & 38 & -3.185 & $.003 *$ \\
\hline
\end{tabular}

between written narratives of personal experiences andwritten narratives of imaginary experiences for language disordered and normal adolescents? The means and standarddeviations of the two groups combined appear in Table VII. By task, the two-way ANOVA found the story grammar components of setting, initiating event, attempt, direct consequence, and reaction to be statistically significantly different at or beyond the .05 level of probability (Table IV). 
MEANS AND STANDARD DEVIATIONS COMBINED FOR THE LANGUAGE DISORDERED AND NORMAL GROUP FOR TASK A (PERSONAL EXPERIENCE) AND TASK B (IMAGINARY EXPERIENCE)

Measure

Task

Mean

SD

setting
A
13.28
10.06

B

9.60

7.35

$\begin{array}{lll}\text { A } & 19.98 & 10.18\end{array}$

Initiating

Event

B

12.83

7.27

$\begin{array}{lll}\mathrm{A} & 4.75 & 6.43\end{array}$

Internal

$\begin{array}{lll}\text { B } & 5.95 & 4.93\end{array}$

Response

$\begin{array}{lll}\mathrm{A} & .30 & 1.31\end{array}$

Attempt

$\begin{array}{lll}\text { B } & 3.53 & 3.54\end{array}$

A

.33

1.00

Direct

B

3.48

3.18

A

.10

.50

Reaction

B

.65

1.27

Post hoc $t$-tests were completed on those story grammar components found to be significant by task based on the ANOVA results to determine if any significant findings existed among the dependent variables for each group. 
TABLE VIII

t-TEST RESULTS ON STORY GRAMMAR COMPONENTS

FOUND TO BE SIGNIFICANT BY THE TWO-WAY ANOVA

BETWEEN TASK A AND TASK B FOR THE

LANGUAGE DISORDERED GROUP

Measure Task Mean S.D. d.f. $\underline{t}$-value p

Setting

A $\quad 6.80 \quad 6.35$

B $\quad 5.50 \quad 3.65$

$19 \quad .818 \quad .424$

A $\quad 16.85 \quad 8.95$

Initiating

Event

B $\quad 13.15 \quad 8.36$

$19 \quad 1.838$

.082

(1)

Attempt

A $\quad .05 \quad .22$

B $\quad 3.25 \quad 3.74$

$19-3.774 \quad .001 *$

$\begin{array}{lll}\text { A } & .15 & .67\end{array}$

Direct

$\begin{array}{llll}\text { Consequence } & B & 3.35 & 3.65\end{array}$

$19-3.984 \quad .001 *$

\begin{tabular}{lrrrrrr}
\hline Reaction & $\mathrm{A}$ & .15 & .67 & & & \\
& $\mathrm{~B}$ & .05 & .22 & & & \\
\hline * = Significant $(\mathrm{p} \leq .05)$ & & & & &
\end{tabular}

Between Tasks $A$ and $B$, no statistical significance was found for the story grammar components of setting, initiating event, and reaction for the language disordered group, while there was significant difference between tasks on the story grammar components of attempt and direct consequence (Table VIII). In each case, the imaginary 
experience task (Task B) led to better performance. Posthoc analysis between the two tasks for the normal group of the five story grammar components revealed that all five were significant, including setting, initiating event, attempt, direct consequence, and reaction (Table IX). These results indicate that a statistically significant difference TABLE IX

t-TEST RESULTS ON STORY GRAMMAR COMPONENTS FOUND TO BE SIGNIFICANT BY THE TWO-WAY ANOVA BETWEEN TASK A AND TASK B FOR THE NORMAL ADOLESCENT GROUP

Measure

Task

Mean

S.D.

d.f.

$\underline{t}$-value

p

setting
A
19.75
8.90

B

13.70

7.89

19

$2.845 \quad .010 *$

A $\quad 23.10 \quad 10.59$

Initiating

Event

B

12.50

6.19

19

$4.510 .000 *$

Attempt

$\begin{array}{lll}\mathrm{A} & .55 & 1.82\end{array}$

B

3.80

3.41

19

$-3.684$

$.002 *$
A
.50
1.24

Direct

Consequence

B

3.60

2.72

19

$-4.905$

$.000 *$

Reaction

A $\quad .05 \quad .22$

B $\quad 1.25 \quad 1.59$

19

$-3.736 \quad .001 *$

$*=$ Significant $(p \leq .05)$ 
exists on five of the six story grammar components for thenormal group between tasks. The personal experience task (Task A) led to better performance for the components of setting and initiating event, whereas the imaginary experience task (Task B) led to better performance in the components of attempt, direct consequence, and reaction. The ANOVA revealed only one statistically, significant interaction of group by task, which was the story grammar component of reaction (Table IV). The mean of reaction components used by the language disordered group on Task A was .15 and .05 on Task B (Figure 1). The mean of reaction components used by the normal group on Task A was .05 and 1.25 on Task B (Figure 1). This indicates that the language disordered group used more reaction statements on Task $A$ than Task B, while the normal group used more reaction statements on Task B than on Task A.

\section{DISCUSSION}

This investigation has sought to answer two questions regarding the written narratives of adolescents about a personal experience and an imaginary experience. This investigation has also sought to gain information about the parameters of normal adolescents' written narratives relative to story grammar analysis, in order to better evaluate and understand the written narratives of language disordered adolescents. 
The data regarding written narratives delineates significant differences for some of the story grammar components between the two groups and between the two tasks. Not surprisingly, except for the category of initiating event on Task B, the normal group used all other story grammar components more frequently than the language disordered group on both tasks. Significant differences between groups were in the categories of setting and internal response on Task $A(P E)$ and the categories of setting and reaction on Task B (IE). Both groups used more setting components on Task A than Task B. The reverse is true of internal responses where both groups used more on Task B than on Task A.

When compared to the language disordered group, the normal group typically scored more setting components because they provided more location descriptions and additional information about the social, physical, or temporal context of the story for both tasks. A representative sample of a scored written narrative for both tasks from each group is included in Appendix $\mathrm{H}$. More internal responses were used by both groups on Task B (IE) because the task itself provided more opportunities for a character's psychological state, plan sequence, and casual relations to be related to an initiating event than Task $A$ $(P E)$. Even so, the normal group used internal responses more consistently across both tasks than the language disordered 
group, suggesting that the language disordered group had great difficulty conveying a character's psychological state (including emotions, goals, desires, intentions, and thoughts), causally relating initiating events, and leading to a plan sequence. These areas of difficulties could be reflective of their deficiencies in pragmatic language. For example, all six of the story grammar components are reflective of the conversational rules of quantity (informativeness), quality (sincerity), relation (topic management), and manner (how to be clear), as described by Grice (1975).

overall, the story grammar component of reaction was rarely used by either group on either task, suggesting it may be a later developing component in the form of a written narrative, or that it is not as appropriate for written narrative analysis as it is for oral narratives. The reaction component was probably found to be significant on Task $B$ because the normal group did increase usage of reaction slightly, as it was causally linked to the story grammar component of direct consequence, as described in the story component criteria (Appendix A) by Merritt and Liles (1987). The language disordered group decreased the usage of reactions in Task $B$, suggesting lack of ability to use or connect the component of direct consequence to a reaction in an appropriate manner.

The language disordered group used a significantly 
greater number of attempts and direct consequences on Task B (IE) than on Task $A$, as did the normal group. once again, this difference can likely be attributed to the nature of the two tasks themselves. More specifically, Task B was designed by Merritt and Liles (1989) "to evoke images of an adventure involving a series of goal-based events" (p.439), whereas Task A (PE) was designed to have all subjects respond to a uniform stimulus that would be guided by their own experiences. Results suggest that since Task A was not necessarily goal-based or adventuresome, it was not an appropriate stimuli to use for comparison with Task B because it does not necessarily follow story grammar format. The data regarding the differences between the imaginary and personal experience narratives of the normal group indicated significant differences exist between five of the six story grammar components, whereas only two categories were significant across tasks for the language disordered group. As expected, this suggests that the normal group used more story grammar components in a conventional, appropriate manner consistent with story grammar usage than the language disordered group. Conversely, when given the stimuli to evoke conventional story grammar usage, the language disordered group did not do so.

Both tasks were not found to be equally useful for assessing language disordered adolescents' narratives with a 
story grammar analysis. The imaginary experience task (Task B) was found to reveal more information about the conventional usage of story grammar rules for the normal group with the exception of the internal response category. Thus results from the analysis of the imaginary experience (Task B) could be set as a standard with which to compare the language disordered group's narratives.

It was expected that the normal group would perform significantly better than the language disordered group on all tasks. That there were not significant differences for each story grammar component suggests, perhaps, that both groups do not have a full understanding of story grammar rules at this level. Conversely, perhaps they do have full understanding of story grammar rules, yet lack a feature of the writing process described by Cambourne (1988). For example, it is likely that the selection and organization of linguistic options is an area of greater difficulty for the language disordered group, and they probably have a more limited linguistic repertoire from which to draw than the normal group. Therefore it is reasonable to assume that the language disordered group attempted to use story grammar rules as best they could, but they were operating from a writing process that was not as well developed as the normal groups. This same writing process described by Cambourne (1988) can also account for differences seen between the two tasks. The imaginary experience (Task B) leads to more of 
the subconscious components described earlier, whereas the personal experience (Task A) could bring a less thoughtprovoking approach, from both groups, in that describing the way a day usually goes can be quite mundane and almost rote.

Reliability between judges was relatively easy to attain, particularly following training sessions using written narratives generated by the normal group. It was more difficult to reach agreement when scoring the language disordered group because some of their narratives were unconventional. But as practice and familiarity with the normal group narratives increased, so did consistency among judges and the investigator when scoring the language disordered group narratives.

\section{LIMITATIONS}

It is necessary to note limitations inherent in this study that could have impacted the results. Though students for whom English is a second language were not used in this study, cultural impact on narratives and the function of literacy on cultures was not controlled. Other limitations not controlled included length of the written narratives, and subjects were not matched by gender so no male/female comparisons were made. Additionally, no measure of pragmatic impact was made prior to this study. 


\section{CHAPTER V \\ SUMMARY AND IMPLICATIONS}

\section{SUMMARY}

The majority of current research about narratives reflects the trend to apply story grammar analysis to children's oral narratives. As children progress through school, their academic performance is increasingly evaluated by their ability to express themselves with written language in a variety of forms, i.e., comparisons, expositions, critiques, hypothetical proposals, and abstract selfexpressions. Therefore, there is a need to apply research techniques to the written narratives of the older student in order to help in the identification of and intervention with language disordered adolescents in the area of written language. Because current research has typically applied story grammar analysis to oral narratives, this investigation is unique in its application of story grammar analysis to written narratives of adolescents.

The purpose of this study was to describe written narratives of language disordered adolescents by comparing their written narratives with those of normal adolescents. The written narratives were obtained by administering two 
tasks as required assignments within the English or communications classes of the two groups. Task A was to write about a personal experience and Task $B$ was about an imaginary experience. This study used Merritt and Liles' adaptations (1987) of stein and Glenn's procedures (1979) for story grammar analysis to describe the content of the narratives.

The following questions were addressed:

1) Do the written narratives of personal experiences and imaginary experiences produce different story schemes in language disordered and normal adolescents?

2) Are there differences between written narratives of personal experiences and written narratives of imaginary experiences for language disordered and for normal adolescents?

Twenty language disordered adolescents and twenty normal adolescents from the Beaverton School District who met the selection criteria served as subjects for this investigation, and ranged in age from 15 years, 2 months to 18 years, 6 months. The written narratives were transcribed into typescript by the investigator and then each utterance was identified as one or more of the six story grammar components. A two-way analysis of variance was performed to determine if differences existed between the two groups and the two tasks. The results indicated a statistically significant difference exists between the two groups on the 
story grammar components of setting, internal response and reaction. Between tasks, significant differences were found on the story grammar components of setting, initiating event, attempt category, direct consequence, and reaction.

In examining the resulting data from this study, it was concluded:

1. Language disordered adolescents did not use as many story grammar components as the normal group when writing about a personal or an imaginary experience.

2. Writing about an imaginary, goal-based event produces more appropriate usages of the story grammar components used than the stimuli given to obtain the personal experience stimuli in this investigation.

3. Whether part of an initial diagnostic assessment or as an ongoing evaluation over time, a story grammar analysis of written narratives is a useful approach to describe individuals' ability to apply story grammar rules that reveal their understanding and use of causally and temporally related information.

\section{IMPLICATIONS}

\section{clinical}

One of the clinical implications arising from this study for speech-language pathologists, particularly those working with adolescents, is that it begins to describe written narratives from only one perspective of story 
grammar analysis. When including a written narrative as part of a diagnostic battery or as a method to obtain written language samples for the purposes of ongoing evaluation, there is a need for speech-language pathologists to have a description of what normal adolescents do on written language tasks, in order to identify what disordered written language is.

This investigation has shown that it is practical and worthwhile to apply a story grammar analysis traditionally used in oral language analysis to written narratives. Story component criteria (Appendix A) can be easily learned by speech-language pathologists and regular classroom teachers and adapted to written narratives to examine language behaviors in the context of story grammars. Once specific components are identified as lacking or less developed from a student's language repertoire, intervention can include a particularly meaningful focus on specific components while working on a written narrative.

This investigation has also shown that certain types of analysis may be more appropriate for some stimuli used to elicit written narratives than others. Specific to this study, using a story stem similar to the one used in this investigation to obtain a written narrative will more likely produce a narrative that lends itself to a story grammar analysis, than having the subject write about a "topic of his choice". Therefore careful consideration should be 
given to the stimuli chosen based on the analysis to be used on the resulting product. When applied to the appropriate stimuli, story grammar analysis is a useful approach to describe individuals'ability to apply story grammar rules that reveal their understanding of causally and temporally related information.

\section{$\underline{\text { Research }}$}

There is a great need for more research to aid in describing the written narratives of language disordered and normal adolescents. Continued research along the same format as this investigation could include collecting multiple written narratives of different goal-based events to look for a consistent usage of story grammars among groups.

Additionally, the narratives collected for this investigation could be described from other perspectives, such as script, text, or communication acts as described by Johnston (1982). For example, the personal experience task (Task A) used in this study may reveal useful descriptions of adolescents' written language when examined using another method of analysis. A different stimuli, such as "write a story about the scariest thing that ever happened to you" could be used to elicit a personal experience that would be more appropriate to the story grammar analysis used in this study. 
A comparison of oral and written responses to identical or similar stimuli would also prove valuable in describing adolescents' language, as well as connecting pragmatic language functions to specific story grammar components. 


\section{REFERENCES}

Alley, G., \& Deschler, D. (1979). Teaching the learning disabled adolescent: Strategies and methods. Denver, CO: Love.

Bloom, L., \& Lahey, M. (1978). Language development and language disorders. NY: Wiley \& Sons.

Cambourne, B. (1988). The whole story: natural learning and the acquisition ofliteracy in the classroom. Auckland, N.Z.: Ashton Scholastic.

Chompsky, C. (1971). Write now, read later. Childhood Education, 47, 296-299.

Dagenais, D.J., \& Beadle, K.R. (1984). Written language: when and where to begin. Topics in language disorders, $3,59-85$.

Grice, H. (1975). Logic and conversation. In P. Cole and J. Morgan (Eds.), Syntax and semantics: Speech acts, 3 . NY: Academic Press.

Gundlach, R.A. (1982). Children as writers: The beginnings of learning to write. In M. Nystrand (Ed.), What writers know: The language, process, and structure of written discourse. NY: Academic Press

Johnston, J.R. (1982). Narratives: A new look at communication problems in older language-disordered children. Language, Speech and Hearing Services in Schools, 13, 144-155.

Johnson, D., \& Myklebust, H. (1967). Learning disabilities: educational principles and practices. NY: Grune \& stratton.

Lahey, M. (1988). Language disorders and language development. NY: MacMillan.

Leonard, L.B., Prutting, C.A., Perozzi, J.A., \& Berkley, R.K. (1978). Nonstandardized approaches to the assessment of language behaviors. Asha, 5, 371-379.

Litowitz, B.E. (1981) Developmental issues in written language. Topics in Language Disorders, 1, 7389. 
Martlew, M. (1986). The development of written language. In K. Durkin (Ed.), Language development in the school years. Cambridge, MA: Brookline Books.

Merritt, D., \& Liles, B. (1987). Story grammar ability in children with and without language disorder: story generation, story retelling, and story comprehension. Journal of speech and hearing research, 30, 539-552.

Merritt, D., \& Liles, B. (1989). Narrative analysis: clinical applications of story generation and story retelling. Journal of Speech and Hearing Disorders, 3 , 438-445.

Myklebust, H. (1965). Development and disorders of written language. Vol. 1. NY: Grune \& stratton.

Myklebust, H. (1973). Development and disorders of written language. Vol. 2. NY: Grune \& stratton.

Poplin, M. (1983). Assessing developmental writing abilities. Topics in Learning \& Learning Disabilities, $3,63-75$.

Read, c. (1981). Writing is not the inverse of reading for young children. In C. H. Frederiksen \& J. F. Dominic (Eds.), Writing: The nature, development, and teaching of written communication. Hillsdale, NJ: Erlbaum.

Roth, F.P., \& Spekman, N.J. (1986). Narrative discourse: Spontaneously generated stories of learning-disabled and normally acheiving students. Journal of Speech and Hearing Disorders, 51, 8-23.

Schumaker, \& Deshler, D. (1984) setting demand variables: a major factor in program planning for the LD adolescent. Topics in language disorders, 2, 22-40.

stein, N. L., \& Glenn, C. G. (1979). An analysis of story comprehension in elementary school children. In R.O. Freedle (Ed.) New directions in discourse processing (pp. 53-120). Norwood, NJ: Ablex.

Westby, C.E. (1984). Development of narrative language abilities. In G.P. Wallach \& K.G. Butler (Eds.), Language learning disabilities in school-age children (pp. 103-127). Baltimore: Williams \& Wilkins.

Westby, C.E., Van Dongen, R., \& Maggart, Z. (1989). Assessing narrative competence. Seminars in speech and language, $1,63-76$. 
APPENDIX A

\section{STORY COMPONENT CRITERIA}

Source: Merritt, D. \& Liles, B. (1987). Story grammar ability in children with and without language disorder: story generation, story retelling, and story comprehension. Journal of speech and hearing research, 30 , 539-552. 


\section{Simone Cutckory}

t intchent is gategorized as a SE1TINC if

1 i major on minor character is introduced. (c.g., "Jim had heen a truckdnver for menty vears." or

2 . Incation is described, or

3 adclitional information is presented that conveys the habit. id social context (e.g., "The boys were usually gone fruin home for only a short time. "), phisical context (e.g. "Life on the islind was hard."), or temporal context of the story, (e g "A worek went loy."), or

1. A Charitcter's habitual state is usiled; the state may not hase. Ineren calused by any previous uccurtence, and may not cause a subsequent event to happen, (e.g., "He was a very (arelul driver.")

\section{Initiating Event Casegory}

A statement is scored as an INITIATINC EVENT if it begins a goal-based episode sequence in the story and causes the main character to respond. Initiating Events include three types of information:

1. A character's action or an event (e.g., "The boys couldn't Gind fresh water or food.").

2. Natural occurrences, which are changes in the physical environment not caused by an animate being (e.g., "One day it had been snowing for many hours." ).

3. Internal events, including a character's internal perception of an external event (e.g., "One day they spotted a ship."), or, changes in the character's internal physiological state (e.g., "By noontime, it was getting harder and harder to breathe.").

Setting and Initiating Events are distinguished from each other in that the Setting provides the contert for the story and the Initiating Event always evokes an immediate response from the character.

Statements that are general events and do not lead to a goal are not scored, for example, "And then they drank water ... and then they ate. ..."

\section{Internal Response Category}

A statement is characterized as an INTERNAL RESPONSE if it meets three criteria:

1. it describes the character's psychological state including emotions, goals, desires, intentions, or thoughts, for example, "He wanted to get home safely," or, "But they knew they could survive if they worked together," or, "They thought that the driver of the truck might be dead." AND.

2. it is causally related to an Initiating Event in the story. AND,

3. it leads to a plan sequence.

\section{Attempt Category}

A statement is categorized as an ATIEMPT if it represents a character's overt action toward resolving the situation or achieving a goal. For example, in Buried Alive, the main character aftempts to get air into his auck by lighting a blowtorch and cutting a hole in the roof

There needs to be a direct causal link or enablement relation between the Attempt and either the Initiating Event or Intermal Response that usually preceeds it or a direct causal link or enablement relation between the $A$ ttempt and subsequent $\mathrm{Di}$. rect Consequence.

\section{Direct Consequence Category}

A statement is categorized as a DIRECT CONSEQUENCE if it marks the direct attainment or nonattainment of the character's goal and is the result of one or more Attempt statements. A Direct Consequence usually leads to a character's reaction, but this may be unstated in the story.

Direct Consequences include three types of information:

1. natural accurrences that influence the resolution of the story by facilitating or impeding attainment of the charac ter's goal, (e.g., "One day the rainy season began.").

2. a character's action that results in either the attainmeat of a god or a chinge in the sequence of events. For example, in Shipurecked, the children built a simple cabin to meet their goul of being sheltered from the rain.

3. End States, (e.g., "They were happy inside the cabin.").

\section{Reaction Category}

REACTIONS define how a character feels about the athinment or nonattainment of a goal (e.g., "Jim was relieved."), what the chanacter thinks about it (e.g., "They knew they were lost"), or an action that is emotional (e.g., "They shouted their thanks.").

A Reaction statement is causally linked to a Direct Consequence, which is usually the preceeding statement. Occasionally, a Reaction preceeds a Direct Consequence, but the causal connection between the statements needs to be apparent.

Reactions usually occus at the end of an episode, but they can also be inserted at other points, for example, if a character pauses to reconsider a consequence and then proceeds. 
APPENDIX B

LETTER TO PARENTS FOR INFORMED CONSENT 
LETTER TO PARENTS FOR INFORMED CONSENT

Dear

and

I am a speech-Language Pathologist in the Beaverton School District. I am currently conducting a research project to complete a Master's Degree at Portland state University under the supervision of Mary Gordon. I am looking for differences and similarities in the way adolescents compose a written narrative when asked to write about a personal experience and an imaginary experience.

This study can be accomplished by giving permission for me to analyze two written assignments that were given in an English class. confidential, and will not be used in reporting the results. choosing to participate, or not to participate, will not affect your child's grade in their English course.

Please read the form below, indicate your approval and willingness to participate in this study, and return the form to me as soon as possible in the envelope provided. An extra copy has been included for you to keep. Please call me if you have any questions (641-7224). Thank you for your cooperation.

\section{sincerely,}

Antigone H. Brown

I hereby give my permission for my child, to participate in the study on adolescents' written narratives, and my child has agreed to serve as a subject in the research project. We understand that the study will involve an analysis of two written assignments that were completed in an English class. We understand that we may withdraw our permission at any time without jeopardizing my course grade or my relationship with Portland state University.

Parent/Guardian Signature Date

If you experience problems that are the result of your participation in this study, please contact the secretary of the Human Subjects Research Review Committee, Office of Grants and Contracts, 303 Cramer Hall, Portland State University, 725-3417. 


\section{APPENDIX C}

\section{STORY GENERATION SCORING PROCEDURE}

Source: Merritt, D., \& Liles, B. (1987). Story grammar ability in children with and without language disorder: story generation, story retelling, and story comprehension. Journal of speech and hearing research, 30, 539-552. 


\section{Story Generation Scornng Procedure}

The following procedural guidelines were adapted from Stein and Glenn's (1979) story grammar to analyze the generated stories:

1. Read each story in its entirety and then separate it into statements, which are defined as either a main clause or a subordinate clause.

2. Divide the story into episodes, with the goal or problem of each episode being identified as a preliminary step.

3. Include a statement in the analysis if it meets the criteria established for one of the six story components listed in Appendix D.

4. Multiple statements can be scored in each category as long as they are connected logically by "AND," "THEN," or "CAUSE" relations, as described by Stein and Glenn (1979).

5. When a statement is expanded upon later in the generated story, only the expanded version is scored unless additional story information is expressed. When this occurs, both statements are scored.

6. Statements are scored even if they are a repetition of the information conveyed in the stem. These statements are always scored as Settings.

7. If a statement meets the criteria for two story components (e.g., a Setting and an Initiating Event) then the statement is scored as both categories.

8. A statement is not included in the analysis if any one of the following conditions is noted:

a) a general comment unrelated to the story, e.g., "I got it," "This is hard," "Ok," etc.,

b) repetition of a thought,

c) an unfinished statement that conveys an incomplete thought, e.g., "He wanted, so, he wanted, then he wanted..."

d) false starts, e.g., "And they found parts of their . . No, I mean ..."

e) formal endings, e.g., "That's it," "The end," etc.,

f) statements in which the information is not specific enough to determine an appropriate story category, either because the referrent is unclear, for example, "And they took him to this place so they could look at it," or because the information cannot be interpreted, for example, "And then, one day, this old lady was in a pilot"

g) extraneous information, usually descriptive, that does not fit into the story grammar analysis.

h) statements that are contradictory, for example, "The family didn't have much water," "So then they went in the house to take a bath." 
APPENDIX D

TASK A PROTOCOL 
Describe the way your day usually

goes, from beginning to end.
Name

Date 
APPENDIX E

TASK B PROTOCOL 
OIRECIIONS: Read the sentence below.

Think about whai might happen next and write

a good story.

NAME :

DATE :

PER.

One day, a pilot was flying through the towering mountains 


\title{
APPENDIX F
}

\author{
STORIES USED FOR RATER TRAINING
}

Source: Merritt, D., \& Liles, B. (1987). Story grammar ability in children with and without language disorder: Story generation, story retelling, and story comprehension. Journal of speech and hearing research, 30, 539-552. 
Story \#1-Buried Alice

1. Iim had been a truckdriver for 20 years. (Setting)

2. He was a very careful driver, (Setting)

3. and he never took chances. (Setting)

4. One day it had been snowing for several hours. (Initiating Event)

5. The roads were getting bad, (Initiating Ev'enl)

6. and Jim could hardly see (Initiating Event)

7. where he was going. (Initiating Event)

8. He wanted to get home safely. (Internal Response)

9. So. he looked for a wide place at the side of the road. (Attempt)

10. pulled over his eighteen-wheeler, (Attempt)

11. and fell fast asleep. (Direct Consecuuence)

12. He was finally able to relax. (Reaction)

13. Jim woke up many hours later. (Setting)

14. It was dark inside the truck, (Setting)

15. but his watch said it was morning. (Setting)

16. The snow on the truck was keeping the sun out. (Initiating Event)

17. Jim knew (Intenal Response)

18. he was trapped. (Internal Response)

19. First, he turned on the windshield wipers. (Attempt)

20. Then he tried to push open the door. (Attempt)

21. But the wipers and the door wouldn't budge. (Direct Consequence)

22. Jim started to worry. (Reaction)

23. By noontime, it was getting harder and harcler to breathe. (Initiating Event)

24. The air in the truck was running out. (Initiating Event)

25. Jin remembered (Internal Response)

26. he had a blowtorch in the back of the truck. (Internal Response)

27. He lit it, (Attempt)

28. cut a hole in the roof, (Attempt)

29. and melted the snow above the hole. (Direct Consequence)

30. Sunlight and fresh air poured in. (Direct Consequence)

31. Jim was relieved, (Reaction)

32. but he knew (Reaction)

33. it would take a long time for all that snow to melt. (Reaction)

34. A whole week went by: (Setting)

35. One day, two state police officers saw an exhaust pipe sticking out of the snow. (Initiating Event)

36. They thought (Internal Response)

37. that the driver of the truck might be dead. (Internal Response)

38. The officers took shovels out of their car, (Attempt)

39. and started digging the snow. (Attempt)

40. About 10 minutes later, they reached the door, (Direct Consequence)

41. and pulled it open. (Direct Consequence)

42. Iim sniled at the officers. (Reaction)

43. He was tired, (Reaction)

44. and he was hungr: (Reaction)

45. But he was alive! (Direct Consequence) 


\section{Story \#2-Shipurecked}

1. Once there were three brothers (Setting)

2. who often fished together in the ocean. (Setting)

3. They were good sailors, (Setting)

4. and usually were gone fron hone for only a short time. (Setting)

5. One day, they all foll asleep on their boat. (Initiating Event)

6. While they slept, (Initiating Event)

7. the anchor broke loose, (Initiating Event)

8. and the boat dritted awily in the dark night. (Initiating Event)

9. It finally crashed against some rocks. (Initiating Event)

10. The boys woke up frightened, (Internal Response)

11. but then saw an island about a mile fron the wrecked boat. (Initiating Event)

12. They swam for their lives, (Attempt)

13. and finally all reached the island. (Direct Consequence)

14. The bovs were grateful to be alive, (Reaction)

15. but they knew they were lost. (Reaction)

16. In the beginning, life on the island was very hard. (Setting)

17. The boys couldn t find fresh water or food. (Initiating Event)

18. But they knew (Internal Response)

19. they could survive (Internal Response)

20). if they worked together. (Internal Response)

21. First, they looked for coconuts. (Attempt)

22. Then they canght birds with their bare hands, (Attempt)

2:3. and cooked thein over an open fire. (Attempt)

24. They always had enough to eat and drink, (Direct Consequence)

25. and never lelt hungry again. (Reaction)

26. The blazing sun was always hot on the island. (Setting)

27. But one day the rainy season begin. (Initiating Event)

28. The brothers knew (Internal Response)

29. they had to build a shelter. (Internal Response)

30. They searched the island (Attempt)

31. and found parts of their wrecked boat. (Direct Consequence)

32. They tied the wond together (Attempt)

33. and built a simple calbin. (Direct Conserquence)

34. They were happier inside the cabin (Reaction)

35. and kept dry when the rain came. (Direct Consequence)

36. The boys still dreamed every night of returning home to their family. (Setting)

37. One day, they spotted a ship. (Initiating Event)

38. They becime excited (Intermal Response)

39. and set fire to some large bushes. (Attempt)

40. The black snoke rose high in the sky, (Direct Consequence)

41. and the ship's captain spotted it. (Direct Conserfuence)

42. He ordered his men to go ashore, (Direct Conseyuence)

4:3. Where the sailors were welcomed by the three brothers. (Reaction)

44. They shouted their thanks. (Reaction)

45. After 15 long months on the island, they were finally going home. (Direct Consequence) 
APPENDIX G

RAW SCORES OF LANGUAGE DISORDERED AND NORMAL ADOLESCENTS ON TASKS A AND B 
LANGUAGE DISORDERED GROUP - TASK A (PE)

$\begin{array}{crrrrrrrr}\text { SUBJECT } & \text { SEX } & \text { S } & \text { IE } & \text { IR } & \text { A } & \text { DC } & \text { R } & \text { ORDER } \\ 1 & \text { M } & 7 & 19 & 0 & 0 & 0 & 0 & \text { 1ST } \\ 2 & \mathrm{~F} & 23 & 29 & 1 & 0 & 0 & 0 & 2 \mathrm{ND} \\ 3 & \mathrm{~F} & 24 & 25 & 6 & 0 & 0 & 0 & 2 \mathrm{ND} \\ 4 & \mathrm{~F} & 4 & 14 & 0 & 0 & 0 & 0 & 1 \mathrm{ST} \\ 5 & \mathrm{M} & 3 & 14 & 3 & 0 & 3 & 3 & 2 \mathrm{nd} \\ 6 & \mathrm{M} & 6 & 15 & 0 & 0 & 0 & 0 & 2 \mathrm{ND} \\ 7 & \mathrm{M} & 1 & 12 & 1 & 0 & 0 & 0 & 1 \mathrm{ST} \\ 8 & \mathrm{~F} & 3 & 4 & 18 & 0 & 0 & 0 & 1 \mathrm{st} \\ 9 & \mathrm{~F} & 4 & 18 & 2 & 0 & 0 & 0 & 2 \mathrm{nd} \\ 10 & \mathrm{M} & 5 & 37 & 1 & 0 & 0 & 0 & 2 \mathrm{nd} \\ 11 & \mathrm{M} & 3 & 18 & 0 & 0 & 0 & 0 & 2 \mathrm{nd} \\ 12 & \mathrm{M} & 0 & 0 & 0 & 0 & 0 & 0 & 1 \mathrm{st} \\ 13 & \mathrm{~F} & 7 & 16 & 1 & 0 & 0 & 0 & 1 \mathrm{st} \\ 14 & \mathrm{~F} & 10 & 9 & 0 & 0 & 0 & 0 & 2 \mathrm{nd} \\ 15 & \mathrm{M} & 2 & 10 & 0 & 0 & 0 & 0 & 1 \mathrm{st} \\ 16 & \mathrm{M} & 3 & 22 & 1 & 0 & 0 & 0 & 2 \mathrm{nd} \\ 17 & \mathrm{M} & 10 & 14 & 2 & 0 & 0 & 0 & 1 \mathrm{st} \\ 18 & \mathrm{M} & 6 & 31 & 0 & 0 & 0 & 0 & 1 \mathrm{st} \\ 19 & \mathrm{~F} & 9 & 10 & 10 & 1 & 0 & 0 & 1 \mathrm{st} \\ 20 & \mathrm{M} & 6 & 20 & 0 & 0 & 0 & 0 & 2 \mathrm{nd}\end{array}$

LANGUAGE DISORDERED GROUP - TASK B (IE)

$\begin{array}{crrrrrrrr}\text { SUBJECT } & \text { SEX } & \text { S } & \text { IE } & \text { IR } & \text { A } & \text { DC } & R & \text { ORDER } \\ 1 & \text { M } & 5 & 12 & 1 & 13 & 4 & 0 & 2 \mathrm{ND} \\ 2 & \mathrm{~F} & 7 & 6 & 7 & 3 & 5 & 0 & 1 \mathrm{ST} \\ 3 & \mathrm{~F} & 6 & 16 & 0 & 1 & 2 & 0 & 1 \mathrm{ST} \\ 4 & \mathrm{~F} & 6 & 7 & 5 & 0 & 0 & 0 & 2 \mathrm{ND} \\ 5 & \mathrm{M} & 3 & 7 & 12 & 5 & 6 & 0 & 1 \mathrm{st} \\ 6 & \mathrm{M} & 2 & 14 & 0 & 3 & 3 & 1 & 1 \mathrm{ST} \\ 7 & \mathrm{M} & 1 & 3 & 4 & 1 & 1 & 0 & 2 \mathrm{ND} \\ 8 & \mathrm{~F} & 7 & 16 & 7 & 1 & 1 & 0 & 2 \mathrm{nd} \\ 9 & \mathrm{~F} & 3 & 16 & 6 & 7 & 7 & 0 & 1 \mathrm{st} \\ 10 & \mathrm{M} & 9 & 29 & 3 & 10 & 15 & 0 & 1 \mathrm{st} \\ 11 & \mathrm{M} & 13 & 33 & 6 & 6 & 8 & 0 & 1 \mathrm{st} \\ 12 & \mathrm{M} & 9 & 9 & 2 & 0 & 0 & 0 & 2 \mathrm{nd} \\ 13 & \mathrm{~F} & 1 & 8 & 1 & 1 & 2 & 0 & 2 \mathrm{nd} \\ 14 & \mathrm{~F} & 13 & 6 & 10 & 0 & 0 & 0 & 1 \mathrm{st} \\ 15 & \mathrm{M} & 2 & 1 & 1 & 1 & 4 & 0 & 2 \mathrm{nd} \\ 16 & \mathrm{M} & 8 & 25 & 11 & 8 & 4 & 0 & 1 \mathrm{st} \\ 17 & \mathrm{M} & 1 & 9 & 0 & 3 & 1 & 0 & 2 \mathrm{nd} \\ 18 & \mathrm{M} & 3 & 15 & 0 & 1 & 1 & 0 & 2 \mathrm{nd} \\ 19 & \mathrm{~F} & 5 & 13 & 2 & 0 & 0 & 0 & 2 \mathrm{nd} \\ 20 & \mathrm{M} & 6 & 18 & 11 & 1 & 3 & 0 & 1 \mathrm{st}\end{array}$

KEY: S=Setting, IE=Initiating Event, IR=Internal Response $A=A$ tempt, $D C=D i r e c t$ Consequence, R=Reaction. 
CONTROL GROUP - TASK A (PE)

$\begin{array}{crrrrrrrr}\text { SUBJECT } & \text { SEX } & \text { S } & \text { IE } & \text { IR } & \text { A } & \text { DC } & \text { R } & \text { ORDER } \\ 1 & \text { F } & 27 & 32 & 16 & 0 & 0 & 0 & \text { 1st } \\ 2 & \mathrm{~F} & 25 & 51 & 11 & 0 & 0 & 0 & 1 \mathrm{st} \\ 3 & \mathrm{~F} & 5 & 23 & 3 & 0 & 0 & 0 & 1 \mathrm{st} \\ 4 & \mathrm{~F} & 34 & 16 & 22 & 0 & 0 & 0 & 1 \mathrm{st} \\ 5 & \mathrm{~F} & 17 & 36 & 2 & 0 & 1 & 0 & 2 \mathrm{nd} \\ 6 & \mathrm{~F} & 21 & 6 & 22 & 1 & 1 & 0 & 1 \mathrm{st} \\ 7 & \mathrm{~F} & 26 & 16 & 10 & 8 & 4 & 0 & 1 \mathrm{st} \\ 8 & \mathrm{~F} & 13 & 19 & 1 & 0 & 0 & 0 & 2 \mathrm{nd} \\ 9 & \mathrm{~F} & 38 & 19 & 9 & 0 & 0 & 0 & 2 \mathrm{nd} \\ 10 & \mathrm{~F} & 31 & 26 & 8 & 0 & 0 & 0 & 2 \mathrm{nd} \\ 11 & \mathrm{~F} & 18 & 32 & 0 & 0 & 0 & 0 & 2 \mathrm{nd} \\ 12 & \mathrm{~F} & 21 & 5 & 0 & 0 & 0 & 0 & 1 \mathrm{st} \\ 13 & \mathrm{~F} & 14 & 26 & 3 & 0 & 0 & 0 & 1 \mathrm{st} \\ 14 & \mathrm{~F} & 20 & 17 & 10 & 0 & 0 & 0 & 2 \mathrm{nd} \\ 15 & \mathrm{~F} & 23 & 18 & 4 & 0 & 0 & 0 & 2 \mathrm{nd} \\ 16 & \mathrm{~F} & 8 & 33 & 3 & 0 & 0 & 0 & 2 \mathrm{nd} \\ 17 & \mathrm{~F} & 6 & 15 & 0 & 0 & 0 & 0 & 2 \mathrm{nd} \\ 18 & \mathrm{~F} & 12 & 23 & 1 & 0 & 0 & 0 & 2 \mathrm{nd} \\ 19 & \mathrm{~F} & 20 & 28 & 17 & 2 & 4 & 1 & \text { 2nd } \\ 20 & \mathrm{~F} & 16 & 21 & 2 & 0 & 0 & 0 & \text { 1st }\end{array}$

CONTROL GROUP - TASK B (IE)

\begin{tabular}{|c|c|c|c|c|c|c|c|c|}
\hline SUBJECT & SEX & S & IE & I R & $A$ & $\mathrm{DC}$ & $R$ & ORDER \\
\hline 1 & $\mathrm{~F}$ & 27 & 24 & 2 & 12 & 5 & 1 & $2 \mathrm{nd}$ \\
\hline 2 & $\mathrm{~F}$ & 20 & 19 & 15 & 13 & 7 & 1 & $2 \mathrm{nd}$ \\
\hline 3 & $\mathrm{~F}$ & 16 & 2 & 4 & 0 & 0 & 0 & $2 \mathrm{nd}$ \\
\hline 4 & $\mathrm{~F}$ & 20 & 12 & 15 & 2 & 4 & 1 & $2 \mathrm{nd}$ \\
\hline 5 & $\mathrm{~F}$ & 11 & 9 & 6 & 2 & 4 & 1 & $1 \mathrm{st}$ \\
\hline 6 & $\mathrm{~F}$ & 12 & 4 & 2 & 2 & 1 & 0 & $2 \mathrm{nd}$ \\
\hline 7 & $\mathrm{~F}$ & 29 & 24 & 12 & 3 & 3 & 2 & $2 \mathrm{nd}$ \\
\hline 8 & $\mathrm{~F}$ & 9 & 14 & 10 & 3 & 2 & 0 & $1 \mathrm{st}$ \\
\hline 9 & $\mathrm{~F}$ & 21 & 10 & 23 & 4 & 7 & 0 & $1 \mathrm{st}$ \\
\hline 10 & $\mathrm{~F}$ & 8 & 14 & 6 & 6 & 4 & 3 & $1 \mathrm{st}$ \\
\hline 11 & $\mathrm{~F}$ & 3 & 5 & 5 & 4 & 5 & 4 & $1 \mathrm{st}$ \\
\hline 12 & $\mathrm{~F}$ & 3 & 9 & 8 & 1 & 1 & 2 & $2 \mathrm{nd}$ \\
\hline 13 & $\mathbf{F}$ & 15 & 17 & 5 & 3 & 3 & 0 & $2 \mathrm{nd}$ \\
\hline 14 & $\mathbf{F}$ & 13 & 11 & 7 & 2 & 1 & 1 & $1 \mathrm{st}$ \\
\hline 15 & $\mathbf{F}$ & 23 & 15 & 7 & 0 & 1 & 1 & $1 \mathrm{st}$ \\
\hline 16 & $\mathrm{~F}$ & 10 & 17 & 3 & 5 & 10 & 0 & $1 \mathrm{st}$ \\
\hline 17 & $\mathrm{~F}$ & 17 & 10 & 4 & 3 & 2 & 2 & $1 \mathrm{st}$ \\
\hline 18 & $\mathrm{~F}$ & 10 & 4 & 3 & 1 & 0 & 0 & $1 \mathrm{st}$ \\
\hline 19 & $\mathrm{~F}$ & 5 & 13 & 8 & 5 & 7 & 6 & $1 \mathrm{st}$ \\
\hline 20 & $\mathrm{~F}$ & 2 & 17 & 4 & 5 & 5 & 0 & $2 \mathrm{nd}$ \\
\hline
\end{tabular}

KEY: S=Setting, IE=Initiating Event, IR=Internal Response $A=\Lambda$ tempt, $D C=D i r e c t$ Consequence, $R=$ Reaction. 
APPENDIX $\mathrm{H}$

REPRESENTATIVE SAMPLES OF WRITTEN NARRATIVES 
Subject \#1 - Language Disordered - Male - Task A

$\checkmark$ Get up at 7:00

IE get dressed

IE go downstairs

IE, s eat breakfast and out of the house by $7: 15$

IE, S to go wait for the bus.

IE, S Then the bus comes by $7: 25$

S,IEthen I get to school by $7: 35$

IE and then I go to all my classes

$S, I E$ and after school I go home

IE and get something to eat

IE then I go out

IE and skate for about 3 hours

IE and I usually go home

IE and get something to eat again

$1 E$ and $I$ turn on $m$ T.V.

IE and usually watch a couple shows

$1 E$ and then I talk to my friends

$1 E$ and after I'm done with that

IE I go to take a shower

IE, 5 and I go to bed by 11:00. 
Subject \#1 - Language Disordered - Male - Task B

S, IE .....and he saw a bunch of kids

IE swimming in a lake.

IE When he was flying he hit a tree,

IF he took a nose dive in the plane

$S, I E$ and then he landed on the ground

$A$ he got out in a hurry

$A$ before the plane blew up

$D C$ or he would have been killed.

$J C$ Now he is stranded

$S$ in the mild of no were

$A$ the first thing he have to do to make a fire

$A$ to keep warm

$A$ also have to make shelter for himself

$A$ so he wouldn't get rained on

$A$ or snow on or anything else

$S$, IE Now the other thing he have to do is find food

IR he's probably hungry

$A$ he can make a fishing, pole

$A$ so he can catch some fish

$A$ to eat for dinner.

16 Every time he saw a plane or a helicopter

$A$ he try to signal it

- by putting his jacket over it uncleal refeunt

$A$ then lifting it up and down

A to make smoke

$\Delta C$ but it didn't work.

S.IE A year later he was hunting for an animal

IE and he just didn't find the right one

5 he found a mountain lion

IE it started running after him

IE it jump on him

IE and killed him

$D C$ it cut his throat and he died from the lion.

Dhe End!!! 
Subject \#14 - Normal - Male - Task A

SAn average school day usually goes well,

$s$ unless there is a important project due that same day

$S$ or a test to be taken.

S,IE In the morning when I get up out of bed around six,

IE I do the average things such as shower, brush my teeth

IE and eat breakfast.

$S$, IE When the time is near seven I leave for the school bus stop.

5 After an almost twenty-fine minute route,

S.IE I arrive at school, Beaverton High.

5 During the ten minutes I have before the starting of first period

IE I usually spend it by studying

IE or completing unfinished homework.

I RMy first few classes aren't too bad.

- There's people literature, government, and health.

IR I able to concentrate in these classes during the morning.

IF In government class, there are tests given

- that in order to pass are necessary to study.

- During English class, there is a lot of writing need to be done.

- In health class there isn't that much homework given out,

IR but I'm not a complainer.

$S$ on the average there is either a film or a class discussion.

SUE The next three, and last, classes I attend are math, biology, and spanish.

5 , JE Nearly every day there is at least math homework given out.

IE Although I am able to finish it during school hours,

$\mathbb{R}_{R}$ it begins to be a pain.

IR Biology class seems interesting at times.

$S, \mathbb{R}$ One day it can be very interesting

SiR while another on another it can seem boring.

- It is necessary not to fall behind in this class.

IR Also, Spanish class is one very important to attend.

5 This class is at third-year level

$I_{R}$ so attending it is very important.

- I also didn't include lunch

- since it isn't considered a class.

$S$, IE After I reach home from school at around three o'clock T, IE I usually do my homework.

$S$ IR It usually depends if I am tired or not.

S. IEOccasionally I will do my homework right away.

IE If the weather is nice out I usually go out.

S. IE At around six o'clock I eat dinner.

5 Then nearly around nine to ten

iE I go to bed. 
Subject \#14 - Normal - Male - Task B

$S$ The pilot's name was Johnson.

5 His co-workers knew him to be courageous at times.

$S$ Although he flew a plane holding air mail,

$S$ he had the skill to make it do wonders in the vast sky.

5 The radio had reported that a heavy wind storm

$\zeta$ was expected to arrive in the next hour.

$S$ Johnson still had at least three hours ahead of him,

$\mathbb{I}, S$ so he decided to land the plane in a small, narrow canyon.

SIE Nearly thirty minutes had passed when Johnson began to hear a strange, unfamiliar sound.

$\mathbb{R} I E$ Concerned, Johnson went out around the plane

IE inspecting its engine.

IE The sound continued.

, e Not knowing any idea of what that sound was,

IE Johnson went back inside the plane

IE and quickly turned on the radio, adjusting it to fine music.

IE Johnson still continued to hear that unbearable noise over the music

$S, I R$ After suspecting it was a wild animal in the dark night,

IR a starting thought crossed his mind.

IE The noise was coming from one of the packages!

5 There was only two fairly large packages in the plane.

- Each one was about the size of two television sets.

$\mathbb{R}$ He first suspected it was a dog,

I $R$ but its sound carried a different tone.

A Johnson then managed to detach both packages from the plane.

S, A After he unloaded them,

$\Delta C$ Johnson became air born again in the wild storm

IE Adjusting the radio to the local news station,

iE the radio announcer reported a murdering of workers in one of the mail airports.

IE It was said that the evidence proved two people seemed to have escaped

5 from the scene near a life and death condition.

$\mathcal{l}$ Johnson gasped! 